\title{
НАВЧАЛЬНО-МЕТОДИЧНІ ПІДХОДИ ДО ВИКЛАДАННЯ ІНОЗЕМНОЇ МОВИ ЗА ПРОФЕСІЙНИМ СПРЯМУВАННЯМ У ЗАКЛАДАХ ВИЩОЇ ОСВІТИ ЗІ СПЕЦИФІЧНИМИ УМОВАМИ НАВЧАННЯ (НА БАЗІ КАФЕДРИ ІНОЗЕМНИХ МОВ ТА КУЛЬТУРИ ФАХОВОГО МОВЛЕННЯ ЛЬВІВСЬКОГО ДЕРЖАВНОГО УНIВЕРСИТЕТУ ВНУТРІШНІХ СПРАВ)
}

Новий підхід до вивчення іноземних мов у закладах вищої освіти зі специфічними умовами навчання, на думку авторів, повинен включати не просто вивчення правил граматики, а також і розвиток найважливіших новітніх комунікативних навичок, як-от критично-аналітичне мислення, вирішення проблем порозуміння з опонентом, самостійне навчання, спілкування та співпраця, з умінням демонструвати ці навички, використовуючи іноземну мову. Вивчення і навчання іноземної мови у відомчих закладах вищої освіти (проаналізовано на прикладі Львівського державного університету внутрішніх справ) - це активний освітньо-пізнавальний процес, який передбачає використання традиційних та інноваційних інтерактивних методів навчання, які базуються на принципах взаємодії та рівності між викладачем $і$ здобувачами вищої освіти, а також проведення різноманітних позааудиторних заходів іноземними мовами, спрямованих на вдосконалення володіння насамперед усним мовленням.

Ключові слова: іноземна мова, інтерактивні методи, здобувач вищої освіти, заклад вищої освіти із специфічними умовами навчання.

Новый подход к изучению иностранных языков в учреждениях высшего образования со специфическими условиями обучения, по мнению авторов, должен включать не просто изучение правил грамматики, а и развитие наиболее важных новых коммуникативных навыков, таких как критическое аналитическое мышление, решение проблем взаимопонимания с оппонентом, самостоятельное обучение, общение и сотрудничество, с умением демонстрировать эти навыки, используя иностранный язык. Изучение иностранного языка и обучение ему в ведомственных учреждениях высшего образования (проанализировано на примере Львовского государственного университета внутренних дел) - это активный образовательно-познавательный процесс, который предусматривает использование традиционных и инновационных интерактивных методов обучения, основанных на принципах взаимодействия и равенства между преподавателем и соискателями высшего образования, а также проведении различных внеаудиторных мероприятий на иностранных языках, направленных на совершенствование владения прежде всего устной речью.

Ключевые слова: иностранный язык, интерактивные методы, соискатель высшего образования, учреждение высшего образования со специфическими условиями обучения.

Bondarenko V. A., Zapotichna R. A., Kashchuk M. H. Educational and methodological approaches to improve the teaching of foreign languages at higher education institutions with

\section{Бондаренко В. А., Запотічна Р. А., Кащук М. Г.}

specific learning conditions (on the basis of the Department of Foreign Languages and Culture of Professional Communication of Lviv State University of Internal Affairs)

In our opinion, the new approach to learning foreign languages at higher education institutions with specific learning conditions should include not only grammar learning, but also the development of advanced skills communication of the twenty-first century, such as critical and analytical thinking, overcoming difficulties in communication with the opponent, independent learning, communication and cooperation with the ability to demonstrate these skills using a foreign language. Learning and teaching a foreign language at higher education institutions with specific learning conditions (on the basis of Lviv State University of Internal Affairs) is an active educational and cognitive process that involves the use of traditional and innovative interactive teaching methods based on the principles of cooperation and equality between teachers and undergraduates, as well as conducting various extracurricular activities in foreign languages, aimed at improving verbal communication skills in the first place.

In the course of teaching foreign languages at Lviv State University of Internal Affairs a special attention is paid to such interactive methods of teaching as Discussion, Cluster, Educational games, Role playing, Grab a Minute, Chain Story, etc. Furthermore, some extracurricular activities conducted by the teachers of the Department of Foreign Languages and the Culture of Professional Communication aimed at mastering and improving language skills are considered in the article, among which different competitions, conferences, exam preparation, distance learning, etc. Undoubtedly, for the successful implementation of all above activities and classes using modern teaching methods and techniques, the teaching staff are constantly improving their scientific and methodological potential and professional level, participating in numerous domestic and foreign events, trainings, webinars, etc.

Key words: foreign language, interactive methods, undergraduate, higher education institution with specific learning conditions.

Вступ. У сучасних умовах глобалізації та інтернаціоналізації освіти й інших сфер суспільного життя змінилося соціальне замовлення - іде пошук спеціалістів, які володіють іноземною мовою на належному рівні. Іншомовна компетентність $€$ одним із критеріїв відбору для професійної зайнятості, передумовою для успішної кар'єри. У зв'язку із цим змінюються і вимоги до

() Бондаренко В. А., Запотічна Р. А., Кащук М. Г., 2020 
навчальної дисципліни «Іноземна мова за професійним спрямуванням» у немовних закладах вищої освіти (зі специфічними умовами навчання також). Якщо раніше основна увага була зосереджена на розвитку навичок читання іноземною мовою, часто застосовувався граматично-перекладний метод, то зараз випускники університету повинні володіти достатньою комунікативною компетентністю для спілкування як у побутовій сфері, так і в колі професійних інтересів. Для цього вони повинні володіти мовними засобами спілкування, мати належні знання, зокрема професійного, правоохоронногота країнознавчого характеру.

Вивчення іноземної мови в немовних вишах передбачає опанування її як засобу міжкультурної комунікації в галузі вищої та післядипломної освіти з метою досягнення освітніх та професійних цілей, а також як засобу самовиховання в галузі професійних інтересів. Мовні навички здобувачів вищої освіти $€$ засобом для отримання нової інформації з іншомовних джерел, спілкування з іноземцями, обміну інформацією, підвищення їхнього культурного рівня тощо.

1. Доцільність зміни парадигми вивчення іноземної мови

Давно в минулому той час, коли в центрі освітнього процесу був викладач. Таке навчання зводилося, на жаль, до пасивної методики, коли головну роль в освітньому процесі відігравав викладач, тоді як студенти (курсанти) були пасивними слухачами. Під час такого навчання викладач подавав матеріал, а далі проводив опитування і здійснював контроль. Сучасна методика викладання будь-якої дисципліни, зокрема й іноземних мов, у закладах вищої освіти спрямована на виховання і навчання здобувачів вищої освіти нового покоління, людей, які мислять, комунікабельних, здатних ухвалювати обдумані, хоч іноді і спонтанні (що особливо характерне для середовища правоохорони), рішення. Така методика сприяє формуванню в тих, хто навчається, умінь працювати індивідуально, у парі чи у групі; надає можливість розуміти і відтворювати те, про що вони думають; підвищує рівень мотивації до вивчення різних предметів, зокрема іноземних мов; створює атмосферу доброзичливості та взаємопідтримки, кооперації та взаєморозуміння на заняттях; розвиває вміння аналізувати, обговорювати та розв'язувати навчальні і професійні завдання.

Безперечно, ідеться про активну методику викладання, яка базується на взаємодії викладача і здобувачів вищої освіти і яку широко використовують викладачі іноземних мов в освітньому процесі Львівського державного університету внутрішніх справ, а саме інтерактивні методи викладання іноземних мов. Саме така методика передбачає рівність між викладачем та здобувачами вищої освіти. В інтерактивній методиці викладання роль науково-педагогічного працівника зводиться до ролі модератора, тобто особи, яка правильно скеровує того, хто вчиться, до ухвалення правильного рішення під час виконання численних різноманітних завдань.

Існує безліч інтерактивних методів, які використовують у викладанні іноземних мов. Ми передусім зупинимося на тих, які успішно і результативно використовують викладачі кафедри іноземних мов та культури фахового мовлення у Львівському державному університеті внутрішніх справ. Звичайно, у процесі навчання викладачі використовують методи, які спрямовані на активізацію всіх видів мовленнєвої діяльності, тобто рецептивних - слухання і читання, продуктивних - мовлення і письма. Проте хочемо зауважити, що більшою мірою акцент ставимо на застосування методів, які сприяють удосконаленню навичок спілкування іноземною мовою, оскільки вміння розмовляти $€$ метою вивчення будь-якої мови.

Зупинимося на характеристиці окремих інтерактивних методів, які, на нашу думку, є ефективними в навчанні іноземних мов, зокрема для майбутніх правоохоронців.

2. Основні інтерактивні методи навчання іноземній мові

Discussion (Дискусія). Цей різновид інтерактивних методів вимагає попереднього вивчення навчального лексико-граматичного матеріалу з метою успішного обговорення певної теми. У разі правильної постановки завдань такий метод дозволяє здобувачам вищої освіти послідовно і логічно висловлювати власні ідеї, обґрунтовувати власну думку. У такому виді діяльності зазвичай викладачі розділяють здобувачів вищої освіти на невеликі підгрупи для залучення кожного до дискусії. Майбутні слідчі й оперативні працівники набувають навиків логічного аналізу в умовах дискусії, а ті, хто готує себе до превентивної правоохоронної діяльності, вчаться вести дискусію з потенційними (або реальними) жертвами чи правопорушниками.

Cluster (B'язка). Один із методів, який часто використовують для активізації нового лексичного матеріалу. Такий метод використовують як на етапі введення нової лексики, так і для закріплення навчальної теми. Так, науково-педагогічний працівник подає новий термін, а здобувачі вищої освіти, своєю чергою, повинні подати ті слова, які поєднуються з даним терміном, тобто утворити різноманітні численні словосполучення. Наприклад, зі словом crime можна утворити такі словосполучення: to commit a crime, to detect a crime, to prevent a crime, to fight against crime, to combat crime, to investigate a crime, a minor crime, a major crime, crime and punishment, a crime scene, etc. Усi здобувачі вищої освіти залучені до виконання такого завдання, отже, удосконалюють свої навики і знання лексичних одиниць.

Одним з ефективних методів, які викладач може використовувати для навчання іноземної мови, $\epsilon$ Educational games (Навчальні ігри). Їх часто використовують як інструмент «розігріву» або коли $\epsilon$ додатковий час, що залишився вкінці заняття. Ігри можуть допомогти активізувати здобувачів вищої освіти, які раніше були пасивними, через відсутність інтересу. Також застосування навчальних ігор під час занять сприяє створенню дружньої і позитивної атмосфери, яка $\epsilon$ необхідною для підтримування продуктивного навчального середовища. Крім того, за допомогою ігр на заняттях викладач «відходить у тінь» та дозволяє здобувачам вищої освіти брати на себе більше відповідальності, бути більш самостійними, що, у свою чергу, підвищує рівень їхньої довіри до викладача. Важливо зазначити, що ігри $є$ ефективним методом для залучення до навчання сором'язливих студентів, особливо коли гра відбувається в невеликих групах, тому що тоді вони отримують можливість виступати перед меншою аудиторією. До того ж іноді легше відкритися під час 
гри, коли атмосфера не настільки серйозна, більше уваги приділяється швидкості, а не граматичній правильності мовлення.

До переваг ігор під час вивчення іноземних мов науковці, серед багатьох інших Е. Госку та К. Каганага, також відносять: формування позитивної мотивації, розвиток критичного мислення й уяви, міждисциплінарний підхід та високий рівень адаптивності до рівня знань здобувачів вищої освіти [1, с. 128-129].

Role playing (Рольова гра) - чи не найпопулярніший інтерактивний метод серед викладачів та здобувачів вищої освіти, який не просто містить елемент навчальної гри, а дозволяє здобувачам вищої освіти відтворити ситуацію професійного характеру, особливо під час вивчення іноземної мови за професійним спрямуванням. Такий метод навчання створює атмосферу співпраці, мотивує, допомагає сформувати практичні навики і вміння. До того ж рольова гра має не лише навчальну, а і соціальну мету, бо у процесі навчання моделюються реальні життєві ситуації. Цей метод особливо корисний для майбутніх правоохоронців, які в ігровій формі можуть відчути себе слідчим, криміналістом, оперативним працівником, патрульним тощо, а також спроєктувати варіанти поведінки правопорушника.

Як приклад наведемо зразок завдання для рольової гри на тему "At the crime scene":

Imagine that you are police officers who arrived at the crime scene. You are going to work in pairs. One of you will be a police officer who is talking to another officer about the following:

- the crime that was committed;

places of possible evidence;

how to protect the evidence of criminal acts.

The second officer - imagine that you are at the crime scene. Talk to the first officer about preserving evidence.

"Grab a minute" («Cxonu хвилинку») - ще один цікавий інтерактивний вид роботи, коли у здобувачів вищої освіти проявляються азарт і мотивація, оскільки за одну хвилину кожен учасник гри повинен надати якомога більше інформації про певну лексичну одиницю, яку подає викладач на дошці чи на картці. У процесі виконання такого завдання важливими $\epsilon$ не тільки швидка реакція здобувачів вищої освіти, але і достатній рівень словникового запасу як загальної, так і фахової лексики.

Chain Story (“Ланцюжкова історія”). Цей інтерактивний метод найбільшою мірою спрямований на співпрацю між здобувачами вищої освіти. Суть гри полягає у продовженні думки чи ідеї попереднього мовця. До того ж такий вид інтерактивного навчання розвиває швидке реагування, мислення, уважність, а також надає можливість активізувати лексичні та граматичні навички.

Безперечно, вище подано перелік лише невеликої кількості інтерактивних методів, які використовують на заняттях викладачі нашої кафедри. Але, на нашу думку, саме такі завдання $\epsilon$ не лише корисними, але i дуже цікавими як для здобувачів вищої освіти, так i для самих викладачів.

3. Інформаційні технології у вивченні іноземної мови

Погоджуємося 3 думкою більшості вітчизняних та іноземних науковців і вважаємо, що важливим у контексті викликів сьогодення $\epsilon$ забезпечення сфери освіти, зокрема і викладання іноземних мов із використанням сучасних, або, як їх ще прийнято називати, нових, інформаційних технологій.

До сучасних технологій у навчанні іноземної мови більшість вітчизняних та іноземних науковців відносять інформаційні й інтернет-комунікаційні технології, роботу з навчальними комп'ютерними програмами з іноземних мов, дистанційні технології, створення мультимедійних презентацій, використання системи соціальних мереж тощо. Сучасні технології допомагають здобувачам вищої освіти засвоїти й удосконалити основні мовні навички, підвищують інтерес до навчального матеріалу, дозволяють зробити навчальний процес більш ефективним та індивідуалізованим.

Усі здобувачі вищої освіти Львівського державного університету внутрішніх справ, які навчаються на факультетах за державним замовленням, зареєстровані на проходження онлайн курсів “Lingva Skills" з вивчення іноземних мов. Понад сотня з них вже отримали сертифікати, що підтверджують знання англійської мови на рівні A1 - A2 або В1 - В1+. Цей онлайн курс дозволяє здобувачам вищої освіти самостійно обирати тематику уроків, зручний час та тривалість навчання.

3 метою вдосконалення викладання іноземної мови у Львівському державному університеті внутрішніх справ кафедрою іноземних мов та культури фахового мовлення започатковано онлайн-курс для самостійного вивчення іноземної мови (англійська). Курс створено з урахуванням Загальноєвропейських рекомендацій з мовної освіти (рівень В1 - В2) і спрямовано на засвоєння мови загального спрямування для підготовки до складання Єдиного фахового вступного іспиту з іноземної мови.

Наявність значної кількості наукових статей, монографій, посібників та дисертацій із педагогічної тематики, висновки яких полягають у рекомендаціях упровадження дистанційних технологій і форм навчання в навчальний процес, вказує на доцільність використання дистанційного навчання й у вивченні іноземних мов. Як зазначають В. Вишнівський та М. Гніденко, «дистанційне навчання являє собою нову організацію освіти, що ґрунтується на використанні як кращих традиційних методів отримання знань, так і нових інформаційних та телекомунікаційних технологій, а також на принципах самоосвіти» [1, с. 5]. Так, під час вимушених карантинних заходів у зв'язку з пандемією коронавірусу викладачі кафедри забезпечили викладання іноземних мов із використанням платформи дистанційного навчання "Moodle”. Використання дистанційних технологій дозволило викладачам розподілити обсяг матеріалу для кожного заняття згідно з розкладом занять та відповідно до кількості годин, відведених на певну тему, та забезпечити виконання навантаження в повному обсязі. Гнучкість дистанційного навчання та багатофункціональність платформи “Moodle" дозволили розробити до кожної теми словник для вивчення фахової лексики, текст на відповідну тему, граматичний матеріал, лексичні і граматичні вправи та завдання до теми для закріплення нового матеріалу, а також тестові завдання для проведення контрольних зрізів знань.

4. Позааудиторні заходи для вивчення іноземної мови

3 метою вдосконалення процесів навчання та вивчення іноземних мов у Львівському державному 
університеті внутрішніх справ, окрім традиційних та інноваційних методів викладання, викладачі кафедри іноземних мов та культури фахового мовлення щорічно проводять різноманітні науково-пізнавальні заходи серед здобувачів вищої освіти, постійно урізноманітнюють їх і вводять щось нове.

Так, уже стало доброю традицією щороку в нашому закладі вищої освіти проводити Всеукраїнську науково-практичну конференцію здобувачів вищої освіти іноземними мовами з актуальних проблем сьогодення. Наукові дослідження здобувачів вищої освіти та відтворення результатів цих досліджень іноземними мовами зокрема - це важливий творчий процес, у якому переважає відчуття самореалізації кожного, адже підготовка до участі в таких наукових заходах - це кропітка праця кожного учасника, під час якої реалізується цілий комплекс завдань перед досягненням кінцевого результату. У процесі підготовки до виступу здобувачі вищої освіти добирають відповідний матеріал на тему свого дослідження, опрацьовують численні джерела іноземною мовою чи відтворюють іноземною мовою той матеріал, який поданий рідною мовою. До того ж вони вчаться відбирати і систематизувати необхідну інформацію, а також публічно виступати іноземною мовою. На нашу думку, проведення таких наукових заходів іноземними мовами сприяє значною мірою вдосконаленню комунікативних навичок здобувачів вищої освіти, оскільки вони не лише покращують свої вміння монологічного мовлення, презентуючи підготовлений матеріал, але й ведуть обговорення проблеми, відповідають на запитання інших.

Здобувачі вищої освіти Львівського державного університету внутрішніх справ традиційно беруть участь у науково-практичних конференціях іноземними мовами не лише в межах нашого закладу вищої освіти, але й в інших закладах вищої освіти України, що дає змогу поділитися знаннями і навичками та розширити географію спілкування.

Для допомоги здобувачам в участі в таких заходах на кафедрі іноземних мов та культури фахового мовлення функціонує гурток “Viva Scientia”, де викладачі проводять поетапні консультації щодо коректного підходу до написання наукової праці та її успішної презентації. Крім того, викладачі кафедри проводять факультативні курси з підготовки здобувачів вищої освіти до складання Єдиного фахового вступного іспиту з іноземної мови для вступу на магістратуру.

Процес вивчення мови тривалий та потребує постійної практики. Тому щороку здобувачі вищої освіти Львівського державного університету внутрішніх справ беруть участь в олімпіаді на краще володіння іноземною мовою. На інтелектуальному змаганні учасники отримують нові знання, здобувають цікавий досвід та розвивають творчий потенціал. На такому заході здобувачі вищої освіти мають змогу продемонструвати навички аудіювання та говоріння, засвоєння граматичного матеріалу, а також проявити креативність.

Щороку кафедрою іноземних мов та культури фахового мовлення проводиться вікторина іноземними мовами «Культура та традиції країн, мова яких вивчається», на якій здобувачі вищої освіти відповідають на запитання вікторини, представляють мультимедійні проєкти та демонструють свої таланти у творчому конкурсі. Такий захід має на меті поглибити знання здобувачів вищої освіти, розвинути їхні мовленнєві навички й узагальнити знання, здобуті на заняттях з іноземної мови.

Ми вважаємо, що проведення всіх вищезазначених заходів викладачами кафедри іноземних мов та культури фахового мовлення сприяє активній методиці навчання іноземних мов, у центрі якого - здобувач вищої освіти, а викладач - консультант, модератор, який правильно скеровує, радить, підказує, мотивує. Саме таке навчання сприяє індивідуалізації навчального процесу, створює умови для реалізації особистісно орієнтованого навчання, формує у здобувачів вищої освіти підвищення самооцінки.

Безперечно, для успішної реалізації всіх вищезазначених заходів і проведення занять із застосуванням сучасних навчальних методик і технік науково-педагогічні працівники кафедри іноземних мов та культури фахового мовлення постійно вдосконалюють свій науково-методичний потенціал та професійний рівень, проходять стажування в закладах вищої освіти України і за їі межами, беруть участь у численних вітчизняних і закордонних заходах, міжнародних науково-практичних та всеукраїнських науково-практичних конференціях, тренінгах, вебінарах. Часто такі заходи відбуваються на базі Львівського державного університету внутрішніх справ, зокрема, за участі Консультативної місії Європейського Союзу в Україні. Чимало працівників кафедри підтвердили свій рівень володіння іноземною мовою (C1). До того ж науково-педагогічні працівники постійно діляться власним досвідом із колегами: проводять показові заняття та щороку формують збірник наукових статей «Актуальні проблеми навчання іноземних мов для спеціальних цілей», у якому діляться методичними напрацюваннями та дослідженнями, а також традиційними та новітніми підходами до навчання іноземних мов.

Висновки. Підсумовуючи викладене вище, можна стверджувати, що головною метою навчання іноземних мов у немовних закладах вищої освіти (особливо зі специфічними умовами навчання) $\epsilon$ підготовка спеціалістів до практичного володіння іноземною мовою із професійно орієнтованим спрямуванням. Тобто опанування іноземної мови розглядається як набуття здобувачами вищої освіти комунікативної компетенції для практичного користування іноземною мовою: здатності працювати з відповідною іншомовною літературою з фаху, брати участь у бесідах та міжнародних конференціях, писати статті іноземною мовою, листуватися з іноземними партнерами, оскільки український спеціаліст має бути конкурентоспроможним, уміти адаптуватися у глобальному суспільстві, застосовувати свої знання у власній практичній діяльності.

Сам процес навчання має бути побудований на принципах інтерактивної взаємодії здобувача з викладачем у різноманітних життєвих ситуаціях. Така взаємодія повинна розвивати самостійність здобувачів, їхню творчу активність і відповідальність за кінцевий результат. Індивідуально орієнтований підхід до навчання і вивчення іноземної мови $є$ сучасним і більш ефективним, ніж суто класичний, спрямований на узагальнення кінцевого результату i розрахований на середнього здобувача. У контексті індивідуально орієнтованого підходу до навчання іноземних мов у Львівському державному університеті внутрішніх справ у теорії та практиці викладання виділяються концепції автономного 
навчання (learn autonomy and autonomous, self-directed learning). Використання такої технології навчання дає можливість здобувачам взяти на себе управління своєю навчальною діяльністю з опанування мови, що вивчається, - здобувач вирішує, що і як він хоче вивчити, бере на себе відповідальність за ухвалені рішення та їх виконання. Водночас здобувач виступає для себе об'єктом і суб'єктом управління, який планує організацію та контролює свої виконавчі дії, частково переймаючи функції викладача на себе. Отже, у процесі навчання іноземної мови та через даний предмет реалізовується завдання розвитку особистості здобувача, формування в нього навичок навчальної діяльності з метою опанування іншомовних компетенцій, здатності самостійно (автономно) управляти даною діяльністю як у конкретній навчальній ситуації, так і в контексті подальшого безперервного вивчення мови.

Як показує повсякденний досвід, здобувачі, які знають граматику іноземної мови і мають досить великимй словниковий запас, часто не можуть подолати мовний бар'єр і вільно викласти свої думки. Здобувач немовного факультету має бути спеціалістом, що вміє спілкуватися іноземною мовою, але кількість аудиторних годин не дає змоги науково-педагогічному працівникові досягти бажаного результату. За такої кількості годин здобувачі більшою мірою мають працювати самостійно, що, з урахуванням специфіки предмета, не $\epsilon$ ефективним, гостро необхідна колективна робота - у групі, у команді, у парі. Зрозуміло, що грамотно та змістовно викладати свої думки можна навчитися насамперед у процесі живого спілкування. Крім того, вивчення мови юридичної спеціальності передбачає засвоєння великої кількості термінів і спеціальних понять, необхідних майбутньому спеціалісту-правнику. Але часу, відведеного на вивчення іноземної мови у відомчих закладах вищої освіти, не завжди досить, щоб опанувати всю необхідну правничу термінологію, тому дуже важливий розвиток у здобувачів навичок роботи зі спеціальними словниками, глосаріями, довідниками за фахом.

\section{До нової концепції юридичної освіти}

Попри те, що самостійну роботу здобувачів часто використовують у навчальних планах як невід'ємну складову частину процесу навчання іноземних мов, а психофізіологічні особливості індивідуума опинилися в центрі уваги освітніх та педагогічних засад у зв'язку 3 демократизацією нашого суспільства, гармонійне поєднання індивідуального підходу 3 організацією самостійної роботи у процесі навчання іноземних мов у немовних закладах вищої освіти (особливо зі специфічними умовами навчання) залишається дуже актуальним і потребує вивчення.

\section{Література}

1. Gozcu E., Caganaga C. The Importance of Using Games in EFL Classrooms. Cypriot Journal of Educational Science. 2016. № 11 (3). P. 126-135.

2. Організація дистанційного навчання. Створення електронних навчальних курсів та електронних тестів / В. Вишнівський та ін. Київ : ДУТ, 2014. 140 с.

Бондаренко В. А., кандидат юридичних наук, доцентка кафедри іноземних мов та культури фахового мовлення

Львівського державного університету внутрішніх справ ORCID ID: 0000-0003-2326-4394

Запотічна P. A., викладачка кафедри іноземних мов та культури фахового мовлення

Львівського державного університету внутрішніх справ ORCID ID:0000-0002-5588-171X

Кащук М. Г., кандидат педагогічних наук, доцентка кафедри іноземних мов та культури фахового мовлення

Львівського державного університету внутрішніх справ ORCID ID: 0000-0001-5881-3280 